Elsevier required licence: (C) $<2015>$. This manuscript version is made available under the CC-BY-NC-ND 4.0 license http://creativecommons.org/licenses/by-nc-nd/4.0/ 


\title{
What drives the allocation of the purchase price to goodwill?
}

\author{
By \\ Martin Bugeja* \\ University of Technology, Sydney \\ and \\ Anna Loyeung \\ University of Technology, Sydney
}

\begin{abstract}
This study examines the proportion of the purchase price allocated to goodwill after the successful acquisition of a publicly listed firm. Using hand collected data we document that $42 \%$ of acquirers record a nil amount for goodwill. We find that the amount allocated to goodwill is generally unrelated to target firm economic characteristics. In contrast, consistent with managerial opportunism we find a positive association between the use of accounting based bonus plans to compensate acquiring firm CEOs and the amount allocated to goodwill. The amount allocated to goodwill also increases after Australia adopted IFRS which no longer required goodwill to be systematically amortised. Other variables associated with goodwill recognition include: the acquiring firm's leverage, the takeover premium, whether the target and the bidder operate in the same industry, existing goodwill in the target firm before the takeover announcement and the method of payment used in the acquisition.
\end{abstract}

JEL Classifications: G34, M40 and M41

\footnotetext{
* Corresponding author: Martin Bugeja, Accounting Discipline Group, The University of Technology Sydney, 2007, New South Wales, Australia. Telephone + 6129514 3743, fax + 61295143669 .

E-mail address: martin.bugeja@uts.edu.au.

Acknowledgements: The author(s) wish to acknowledge the comments of Majella Percy, Zoltan Matolcsy and Peter Wells and participants at the JCAE Mid-year conference in Hobart 2015, AFAANZ conference in Auckland 2014, EAA annual meeting in Estonia 2014 and a seminar at Koc University.
} 
$\mid$ 


\section{Introduction}

Following a business combination, accounting standards require consolidation of the acquired entity into the acquiring firm's financial statements. As part of the first time consolidation the parent entity is required to allocate the purchase price to the tangible and identifiable intangible assets and liabilities acquired (AASB 3: 'Business Combinations'). As this allocation is based on the fair value of the respective assets and liabilities the acquiring firm has significant discretion as to how to allocate the purchase price. Any residual between the purchase price and the fair value of the identifiable net assets of the acquired firm is then recorded as goodwill. The objective of this study is to examine the proportion of the purchase price allocated to goodwill. Specifically, we investigate whether the allocation of the purchase price to goodwill after an acquisition is explained by opportunism, takeover characteristics and the underlying financial characteristics of the target and bidding firms.

The motivation for this study is twofold. Firstly, empirical evidence on the allocation of the purchase price after successful corporate acquisitions is limited. Given that there is discretion in undertaking this allocation, further evidence is needed on whether allocations reflect underlying target and bidding firm economic characteristics or are driven by managerial opportunism (Holthausen and Watts 2001). Consistent with managerial opportunism, Shalev et al. (2013) finds an over-allocation of the purchase price to goodwill when U.S. CEOs receive bonuses tied to accounting earnings as this, results in increases in post-acquisition earnings. Their study however, is conducted in a setting where goodwill is required to be impaired and not required to be amortised post-acquisition. We aim to add to the findings of Shalev et al. (2013) by investigating a setting where goodwill accounting changed from systematic amortisation to annual impairment. The Australian setting allows us to understand how a change in accounting standards impacts on management's incentives when firms transition from local GAAP (systematic amortisation setting) to IFRS (annual impairment setting).

Secondly, we add to prior research by investigating whether takeover deal characteristics impact on goodwill recognition. While goodwill recognition is the outcome of a successful acquisition, prior studies have generally ignored the fact that takeover characteristics such as, friendly/hostile acquisitions, synergic acquisitions and the bidding firm toehold may also explain the amount of recognised goodwill. We argue that when the bidding firm has more information about the target prior to the acquisition, less goodwill is recognised. In this instance the bidding firm is able to value the target with more certainty and as a result 
is unlikely to overpay. Furthermore, as goodwill is a measure of acquisition synergies, it is expected that more goodwill is recorded when synergistic acquisitions occur.

Using a sample of 308 successful Australian takeovers from 1998 to 2012 we document that in $42 \%$ of takeovers the acquiring firm records neither goodwill nor a bargain purchase. This high proportion of takeovers with no recorded goodwill is unexpected as it indicates that the cost of acquisition in these takeovers is exactly equal to the fair value of the identifiable net assets acquired. This finding suggest that bidding firms managers may be using their discretion to avoid the costly process of undertaking an accurate purchase price allocation, which includes complex valuation exercises.

We then conduct an analysis of the factors which are associated with the proportion of the purchase price recorded as goodwill. Consistent with managerial opportunism we find that CEOs with an accounting based bonus plan allocate a greater proportion of the purchase price to goodwill both before and after IFRS adoption. This finding suggests that the U.S. results of Shalev et al. (2013) hold in both a goodwill impairment setting and in a goodwill amortisation setting. We also find that the proportion of the purchase price allocated to goodwill increases after Australia adopted IFRS. This result suggests that firms took advantage of the change in accounting requirements by allocating more to goodwill (and less to other depreciable assets) so as to achieve an improvement in profitability. Inconsistent with prior findings (e.g., Wong and Wong, 2001), we document that the amount allocated to goodwill increases with bidding firm leverage.

In terms of takeover characteristics, we find a positive association between takeover premiums and acquired goodwill. This result is expected since a higher premium increases the purchase price and this increased amount is likely to flow into the amount recorded as goodwill. In contrast to expectations, we find a negative association between synergistic acquisitions (i.e., target and bidders which operate in the same industry) and goodwill recognition. In terms of target and bidding firms' underlying economic characteristics we document a positive association between the goodwill and the existing goodwill of the target firm suggesting that these assets remain part of the unidentifiable intangible assets acquired by the bidding firm. Other economic characteristics of the target and bidder firms however, are not associated with the proportion of the purchase price allocated to goodwill. Our results also indicate that the amount recorded as goodwill is positively associated with the use of cash payment. 
We contribute to the academic literature in a number of ways. Firstly, we extend the accounting choice literature (Fields et al., 2001 and Armstrong et al., 2010) by examining managers' use of discretion in the decision on how to allocate the purchase price in acquisitions. Our findings suggest that when given accounting flexibility, some managers use their discretion to adjust the amount of the purchase price in a business combination that is allocated to goodwill. Secondly, our results indicate that the purchase price allocation is conditional on a number of target firm specific factors and takeover characteristics. This finding is of importance to research which examines the value relevance of goodwill and goodwill impairment (Barth and Clinch 1996; Jennings et al. 1996; Godfrey and Koh 2001; Dahmash et al. 2009) as our results indicate that goodwill is endogenously determined. As such, the factors that are associated with the purchase price allocation are also likely to be associated with the value relevance of goodwill.

Secondly, we extend previous research which examines the consequences of the adoption of IFRS (Barth et al., 2008; Daske et al., 2008; Chalmers et al., 2011a; Chalmers et al., 2012, Cotter et al., 2012; Horton et al., 2013; Lai et al., 2013). Assuming that the purchase price allocation reflects the underlying characteristics of the takeover and the target and acquiring firms, changes in accounting rules are not expected to influence the amount allocated to goodwill. In contrast, if the purchase price allocation reflects opportunism we predict that pre-IFRS acquiring firms allocated a lower percentage of the purchase price to goodwill. This expectation arises because during that time period there was discretion available in regards to the amortisation of intangible assets and no discretion regarding the amortisation of goodwill. Furthermore, we also expect that after goodwill amortisation was removed (i.e. post- IFRS) that the under allocation of the purchase price to goodwill is reduced. Our results are consistent with this expectation.

The remainder of this paper is structured as follows. The next section provides the background to accounting for business combinations in Australia and related research. Section 3 develops the theory and describes the research method. Section 4 provides a discussion of the data collection process. Results of our analysis are presented in section 5, whilst section 6 concludes the paper.

\section{Background}

\subsection{Accounting for goodwill in Australia}


The accounting requirements for corporate acquisitions in Australia are currently prescribed in AASB 3 'Business Combinations.' This standard requires goodwill to be measured as the difference between the purchase consideration and the fair value of the identifiable net assets acquired (paragraph 32). Where the purchase consideration is not cash the purchase consideration must be measured using the fair value of the assets or equity provided as consideration (paragraph 37). Prior to Australia's adoption of IFRS, ${ }^{1}$ the amount recorded as goodwill was systematically amortised to earnings over a maximum period of 20 years (AASB 1013 'Accounting for Goodwill'). After the adoption of IFRS however, AASB 136 'Impairment of Assets' requires that goodwill is no longer amortised but is subject to annual impairment testing.

Johnson and Petrone (1998) separate the amount recorded as purchased goodwill into the following components:

i) The difference between the fair value and book value of the target firm's recognised net assets;

ii) The fair value of net assets not recognised by the target firm such as internally generated intangible assets;

iii) The fair value of the going concern component of the target firm as a standalone business (i.e., internally generated goodwill);

iv) The fair value of any synergies arising from the business combination between the target and bidding firms (i.e. purchased goodwill);

v) Over or undervaluation of the consideration paid by the bidder.

vi) Over or under payment by the bidder

Under the requirements of the accounting standards only components iii) and iv) should be recorded as goodwill. Components i) and ii) are required under accounting standards to be recorded separately as part of the business combination. However, in practice due to measurement difficulties or a lack of expertise by the acquiring firm and their auditors it is possible that these components are included as part of goodwill. Similarly, components v) and vi) do not represent goodwill but are likely to be included in the amount designated as goodwill due to this amount being recorded as the residual balance. As the manner of calculating goodwill relies on estimating the fair values of non-traded assets managers are afforded

\footnotetext{
${ }^{1}$ Australian firms with financial years ending 31 December adopted IFRS in 2005 and Australian firms with financial year ending 30 June adopted IFRS in 2006.
} 
significant discretion in determining the amount allocated to any class of assets and ultimately goodwill.

\subsection{Related research on goodwill}

The accounting for purchased goodwill has been the subject of controversy for many years. The first point of contention regarding purchased goodwill is whether acquired goodwill is an asset (Johnson and Petrone 1998). The recognition of goodwill as an asset is problematic as it is arguable as to whether goodwill provides future economic benefits. As a reflection of the uncertainty as to whether goodwill is an asset, the preferred treatment of the earlier UK accounting standard was that goodwill acquired in an acquisition be immediately written-off to reserves (Standard Accounting Practice 22: 'Accounting for Goodwill'). To test whether goodwill warrants reporting on the balance sheet as an asset prior studies have examined the value relevance of goodwill (Chauvin and Hirschey 1994; Barth and Clinch 1996; Jennings et al., 1996; Godfrey and Koh 2001; Bugeja and Gallery, 2006; Dahmash et al., 2009). Generally, these studies find that investors view recorded amounts of goodwill as representing valuable economic resources.

Another area which has been investigated in prior literature is the treatment of goodwill post- recognition. Until recently, most countries required that goodwill be subject to periodic amortisation with additional write-offs (i.e., impairments) required if goodwill was considered impaired. For instance, until the issue of Statement of Financial Accounting Standard No. 142 (SFAS 142: 'Goodwill and Other Intangible Assets)' in 2001, goodwill in the U.S. was required to be amortised over a maximum period of 40 years. Empirical studies in this area have shed light on the causes and market reaction to goodwill write-offs.

In terms of the causes of goodwill write-offs, prior studies document that acquisition characteristics and performance indicators are associated with goodwill write-offs. Goodwill impairment has been found to be positively associated with the payment of higher takeover premiums and the amount initially recorded as goodwill (Hayn and Hughes 2006; Gu and Lev 2011 and $\mathrm{Li}$ et al., 2011). Empirical findings also suggest that the component of consideration paid using overvalued stock is positively associated with goodwill impairment (Hayn and Hughes 2006; Gu and Lev 2011 and Li et al., 2011). Goodwill impairment frequency has also been found to be lower in focus enhancing acquisitions (Li et al., 2011) and in takeovers made by firms with strong corporate governance mechanisms (Gu and Lev 2011). Furthermore, Godfrey and Koh (2009) find that goodwill impairment charges in the U.S. are negatively 
related to a firm's investment opportunity set. In the Australian setting, Chalmers et al. (2011b) find that goodwill charges are negatively associated with a firm's investment opportunity set only in the goodwill impairment regime (i.e. post- IFRS).

Evidence on the market reaction to goodwill write-offs provides mixed findings. While Francis, et al. (1996) find little share price reaction to goodwill write-offs, others have documented evidence of negative abnormal returns (e.g. Hirschey and Richardson 2002; Hayn and Hughes 2006; Bens et al. 2011; Li et al. 2011). Furthermore, Abu Ghazaleh et al. (2012) document a significantly negative association between goodwill write-offs and the market value of equity.

Prior research has also documented that when given a choice managers often prefer to minimise the amount recorded as goodwill. For example, prior to the introduction of an enforceable accounting standard the most common methods used to account for goodwill in Australia avoided systematic amortisation (Gibson and Francis 1975; Anderson and Zimmer 1992). U.S. research has studied reasons for firms' preference for the pooling rather than the purchase method of accounting for acquisitions and concludes that this choice is driven by a desire to maximise reported earnings (Gagnon 1967; Copeland and Wodjak 1969; Aboody et al., 2000 and Ayers et al., 2002).

More recently Shalev et al. (2013) study the amount allocated to goodwill for a sample of U.S. acquisitions. Consistent with opportunism they find evidence showing an overallocation to goodwill by firms whose CEOs receive a greater proportion of their remuneration from accounting based bonus-plans. As goodwill is not amortised, allocating a higher amount of the purchase price to goodwill likely increases post-acquisition earnings and bonuses. However, as their study takes place solely during a period of time when accounting standards required goodwill to be impaired, they do not provide evidence on whether the move from goodwill amortisation to impairment changed the proportion of the acquisition price allocated to goodwill. This study provides such evidence.

\section{Theory development and research method}

\subsection{Determinants of the purchase price allocated to goodwill}

\subsubsection{Opportunism}

Under the opportunistic view, managers use their discretion to either over or under allocate the purchase price to goodwill. The likelihood of opportunistic behaviour arises 
because the measurement of goodwill requires numerous estimates of fair values when assigning the purchase price to identifiable net assets (Holthausen and Watts 2001; Ramanna 2008). In particular, the majority of assets acquired are unlikely to be traded on active markets increasing the need for subjective fair value estimates. We argue that managers may use this discretion to opportunistically determine the amount recorded as goodwill for a number of reasons. For instance, firms may have incentives to minimise the costs of completing an accurate purchase price allocation. As mentioned in section 2.1, the accounting standard requires acquiring firms to calculate the fair values of both recorded and unrecorded target firm identifiable net assets when calculating goodwill. This exercise is complex and requires an acquiring firm and their auditors to undertake difficult and costly valuation exercises. For some firms it may be simpler and less costly to simply pro rata the value of the purchase consideration across the non-monetary assets of the target firm so that the amount allocated to such assets equates to the purchase consideration resulting in no goodwill being recorded. An additional incentive for recording a nil balance of goodwill is that it also avoids the complex annual task for preparers and auditors of testing the goodwill balance for impairment. ${ }^{2}$ Finally, recognising a nil amount of goodwill means that firms do not have to recognise decreases in postacquisition earnings either through systematic amortisation or irregular impairment charges.

In line with managerial opportunism, we expect the decision to recognise goodwill to be associated with the financial reporting environment. Prior to Australia's adoption of IFRS, goodwill was amortised for a period not exceeding 20 years which decreases post-acquisition profits. This gives managers an incentive to report higher earnings by allocating more of the purchase price to longer lived assets or to assets with an indefinite life and less to goodwill, to avoid recording the systematic goodwill amortisation expense. This expectation is supported by prior research which suggests that managers prefer to avoid the amortisation of goodwill due to its income decreasing effect. For example, Gore et al. (2000) report that U.K. CEOs with profit based compensation plans prefer to immediately write-off goodwill to reserves as opposed to recording goodwill as an asset. Furthermore, U.S. research indicates that firms are willing to pay an additional premium to qualify for the use of the pooling method of accounting and hence avoid the need to amortise goodwill (Robinson and Shane 1990 and Ayers et al.,

\footnotetext{
${ }^{2}$ Prior to Australia's adoption of IFRS goodwill was also tested annually for impairment (AASB 1013 paragraph 5.4). In 2009, The IASB issued IFRS for Small and Medium Sized Entities (SME's) which highlights that accounting standard setters recognise the complexity of goodwill impairment testing. That standard requires SME's to amortise goodwill over its estimated useful life, with the life set at 10 years if it cannot be reliably estimated (paragraphs 18.19, 18.20 and 19.23).
} 
2002). This line of research suggests that firms are reluctant to record goodwill when it needs to be amortised. ${ }^{3}$ Thus, it is expected that before the adoption of IFRS in Australia, managers used their discretion to recognise less goodwill.

Post- Australia's adoption of IFRS, however, goodwill was no longer subject to amortisation but was subject to annual impairment testing. If managers act opportunistically they have an incentive to over-allocate an amount to goodwill as opposed to other depreciable assets to avoid a systematic annual charge against earnings (Shalev et al., 2013). A counter argument is that over-allocating an amount to goodwill increases the probability that the firm needs to impair goodwill which potentially increases earnings volatility post-acquisition. There are also costs associated with the subsequent impairment of goodwill such as negative stock returns (e.g. Bens et al., 2011; Li et al., 2011) and a decrease in firm value (e.g. Abu Ghazaleh et al., 2012). Although these capital market effects may motivate managers to not over-allocate an amount to goodwill we argue that there is an important difference between goodwill impairment and amortisation. In particular, managers have greater discretion as to when an impairment charge is recorded compared to certain annual amortisation. Additionally, it is unlikely that at the time of making a takeover that bidding firm management expects that they will subsequently need to impair goodwill, particularly if they are 'infected' with hubris (Roll 1986).

There are also likely to be contractual incentives for managing the amount recorded as goodwill. First, goodwill and other intangible assets are typically not included in the calculation of leverage in debt contract covenants (Cotter, 1998), prompting managers to allocate more of the purchase price to tangible assets rather than to goodwill (e.g. Grinyer et al., 1991; Wong and Wong 2001; Beatty and Weber 2006). ${ }^{4}$ Second, when CEOs receive a higher level of compensation which is tied to accounting earnings they have an incentive to manipulate the

\footnotetext{
${ }^{33}$ Accounting standards in Australia have never allowed the use of the pooling method of accounting.

${ }^{4}$ Beatty and Weber (2006) document that more than 50 per cent of bank debt contracts had covenants that exclude goodwill (amongst other intangible assets). In terms of the association between goodwill and leverage, Grinyer et al. (1991) find that the amount of goodwill is negatively related to acquiring firm leverage. Wong and Wong (2001), however, argue that this finding is also consistent with an investment opportunity set explanation. They find that the amount allocated to goodwill for a sample of New Zealand takeovers is higher for firms with lower leverage and interpret their result to indicate that firms with lower leverage have a better investment opportunity set and as a result allocate a greater amount to goodwill. The influence of leverage on goodwill recognition is also examined by Gore et al. (2000). They study management's preference for capitalising goodwill or immediately writing goodwill off against reserves using a survey conducted in the UK. They find that manager's prefer goodwill capitalisation when their firm has high gearing and a gearing based debt covenant restriction in place as the immediate write-off option would have the effect of increasing gearing by reducing firm equity.
} 
amount recorded as goodwill to maximise their remuneration (Watts and Zimmerman 1990; Shalev et al., 2013). Thus, we expect that prior to the adoption of IFRS, when a firm compensates their CEO using an accounting based bonus plan that the firm minimises the amount allocated to goodwill to avoid goodwill amortisation and hence maximise earnings. Furthermore, when goodwill amortisation was replaced by impairment post- IFRS we expect this association to reverse.

Therefore under the opportunistic view, managers use their discretion to manage the amount allocated to goodwill. This leads to the first hypothesis.

$H_{1 a}:$ The amount allocated to acquired goodwill increases after the adoption of IFRS and decreases with bidding firm leverage.

$H_{1 b}$ : The amount allocated to acquired goodwill is associated with the use of CEO bonus plans based on accounting profit.

\section{Monitoring of opportunistic behaviour}

In order to curb managerial discretion and to protect the interest of shareholders, firms are likely to put monitoring systems in place. We take the view that Big 4 auditors provide higher quality audits and object to managerial discretion to misreport the accounts (e.g. Francis and $\mathrm{Yu}, 2009$ ). Also, Big 4 auditors possess more expertise and resources than non-Big 4 firms and are better able to accurately identify unrecognised intangible assets and to also value both recognised and unrecognised target firm assets. In contrast, non-Big 4 auditors are perhaps more likely to accept a simplistic approach of proportionately allocating the purchase price across existing target firm net assets resulting in no goodwill being recorded. Big 4 auditors are also more likely to have the skills to conduct complex goodwill impairment testing. Therefore, we expect that bidders audited by a Big 4 audit firm to report more goodwill as Big 4 audit firms have both the ability to measure goodwill accurately and the incentives to curb managers' discretion to prepare their purchase price allocation opportunistically.

Furthermore, it is possible that the relative size of the target firm to the bidding firm impacts on the acquirer's decision to recognise goodwill. Grinyer et al. (1991) argue that takeovers which are considered large compared to the bidding firm's size attract more attention (for example, from the media). In this instance, we expect managers to exercise less discretion and expect that they devote more resources to achieving greater accuracy in the allocation of the purchase price to the various assets, including goodwill. Auditors are also likely to pay 
greater attention to the purchase price allocation in larger takeovers due to materiality reasons. As a result, we expect a positive association between the relative size of the takeover and acquired goodwill.

In summary, external monitoring from audit firms and other stakeholders are expected to curb managers' discretion in misreporting acquired goodwill suggesting a positive association between acquired goodwill and monitoring practices. This leads to our second hypothesis.

$H_{2}$ : There is a positive association between acquired goodwill and the use of Big 4 auditors and the relative size of the acquisition.

\subsubsection{Takeover deal characteristics}

The successful acquisition of a target firm is the result of extensive negotiations between the bidding and target firm. We argue that a number of takeover characteristics influence the amount allocated to goodwill as they impact the purchase price. We argue that greater access to information about the target firm gives the bidder an increased ability to accurately identify and value the target firm assets both before and after making a bid. As a result, the consideration offered is expected to be closer to the fair value of the net identifiable assets leading to a lower risk of overpayment and hence a reduction in the amount recorded as goodwill (i.e., category vi. of Johnson and Petrone 1998).

A higher ownership interest by the bidder in the target firm prior to the takeover (i.e., toehold) is likely to give the bidder greater access to target firm financial information prior to the takeover. This better information set may arise for example through the preparation of equity accounting. In addition, a prior equity stake in the target may provide the bidding firm with the ability to appoint a director to the target firm board thus reducing information asymmetry. Hence, we predict a negative association between the pre- takeover ownership interest of the bidding firm and acquired goodwill.

Whether the takeover is friendly or hostile is also expected to be associated with acquired goodwill. In friendly takeovers, the target firm typically grants permission for the bidder to conduct due diligence. This due diligence process provides the bidder with more detailed information on the value and existence of target firm assets and as a result the bidder 
may be less likely to over pay for the target firm. As a result, we predict a negative association between friendly takeovers and acquired goodwill.

A higher takeover premium may result in a greater amount of the purchase price being recorded as goodwill. The additional premium is expected to flow through to the amount recorded as goodwill, given that goodwill is calculated as the difference between the acquisition price and the target firm net identifiable assets. Takeover premiums may also reflect the acquisition synergies that the bidding firm expect from an acquisition (Hayn and Hughes 2006; Sudarsanam and Sorwar 2010). ${ }^{5}$ Arguably operating synergies are expected to be greatest when the bidding firm and the target firm are in the same industry. Given that goodwill is argued to be a measure of acquisition synergies, we expect the takeover premium and acquisitions in the same industry as the bidder to be positively associated with goodwill recognition.

Finally, we argue that the payment method used (equity versus cash) may also explain the amount of the purchase price allocated to goodwill. Results from prior research suggest that the bidding firm is likely to pay higher premiums when the payment method is cash (e.g., Bugeja and Da Silva Rosa 2010). As a result, we expect more goodwill to be recorded when the payment method is cash. Moreover, equity payments by the bidding firm may indicate that the equity of the bidding firm is overvalued (Myers and Majluf 1984). This overvaluation is likely to increase the amount recorded as goodwill. Given the two competing views, we argue that there is an association between the payment method and the amount of the purchase price recorded as goodwill but do not make a prediction as to the sign of the direction.

The above arguments lead to the following hypotheses.

$H_{3 a}:$ There is a negative association between acquired goodwill and the bidding firm toehold and friendly acquisitions.

$H_{3 b}:$ There is a positive association between acquired goodwill and takeover premiums and acquisitions in the same industry.

$H_{3 c}:$ There is an association between acquired goodwill and the payment method.

\subsubsection{Economic characteristics of the target and bidding firm}

\footnotetext{
${ }^{5}$ A higher takeover premium is also paid if managers suffer from hubris or overconfidence whereby they overestimate their ability to generate future returns (Roll 1986; Malmendier and Tate 2008).
} 
The purchase price allocation to goodwill should fundamentally be determined by the underlying economic characteristics of the target and the bidding firms. We argue that more goodwill is recognised in acquisitions of target firms which have greater amounts of existing goodwill prior to the acquisition. The existing goodwill of the target firm is expected to remain part of the unidentifiable intangible assets identified by the bidding firm (Shalev et al., 2013). Furthermore, the method of accounting for a business combination requires the recording of all tangible and identifiable intangible assets at fair value before calculating the amount of goodwill. Therefore, it is expected that a higher amount of acquired target firm tangible and intangible assets pre-acquisition reduces the amount allocated to goodwill.

From an efficiency point of view, goodwill is a measure of value creation. Goodwill is recognised as the bidding firm believes that it will earn future 'surplus' profits from its investment in the target firms compared to an alternative investment with similar level of risks (Bryer 1995 p.286). These 'surplus' profits arise for a variety of reasons including good customer relations, good employee relations, acquisition of technical and managerial talent, and monopoly power, which cannot be separately identified and valued (Tearney 1973; Chauvin and Hirschey 1994). We argue that the bidding firm adjusts the purchase consideration to recognise the future synergies and higher future firm performance ensuing from their acquisition which in turn increases the amount of acquired goodwill.

Finally, Li et al. (2011) argue that overvalued bidders are more likely to overpay in an acquisition. This overpayment is expected to overstate the amount allocated to goodwill since goodwill is the residual between the purchase price and the identifiable net assets acquired. As a result, we argue that there is a positive association between acquired goodwill and overvalued bidders.

The above discussion leads to the following hypotheses:

$H_{4 a}$ : There is a positive association between acquired goodwill and the existing goodwill of the target firm, the target firm's growth potential and overvalued bidders.

$H_{4 b}$ : There is a negative association between acquired goodwill and existing tangible and identifiable intangible assets of the target firm.

We empirically test the factors that influence the choice to record goodwill using the following tobit regression model: ${ }^{6}$

\footnotetext{
${ }^{6}$ A tobit regression is used since the amount allocated to goodwill is censored at zero.
} 
$G W \_D V=\alpha_{i}+\beta_{I} I F R S+\beta_{2} B \_L E V+\beta_{3} B O N U S+\beta_{4} I F R S x B O N U S+\beta_{5} B I G 4+\beta_{6} R E L S I Z E+$ $\beta_{7}$ TOEHOLD $+\beta_{8} F R I E N D L Y+\beta_{9} P R E M I U M+\beta_{10} S A M E I N D+\beta_{11} P A Y C A S H+\beta_{12} T \_G W \_D V$

$+\beta_{13} T \_P P E \_D V+\beta_{14} T \_I I A \_D V+\beta_{15} T \_M B+\beta_{16} B \_M B+\varepsilon_{i}$

The dependent variable $G W_{-} D V$ is the dollar value of the purchase price allocated to goodwill scaled by deal value. Our first set of variables capture managerial opportunism. To identify takeovers in which the first year of consolidation occurs after Australia adopted IFRS we include in the model an indicator variable (IFRS). We also control for contractual incentives to manage the amount allocated to goodwill. Bidder firm leverage ( $B \_L E V$ ) measured using the ratio of debt to equity for the financial year prior to the acquisition is used to control for the incentive of firms to allocate the purchase price to tangible assets which are included in debt covenant ratios. The influence of CEO bonus plans is controlled in the model using an indicator variable coded as one if the firm compensates their managers using a bonus plan based on accounting earnings (BONUS). This variable is also interacted with the IFRS indicator variable to determine whether the association between CEO compensation structure and the amount allocated to goodwill changed after the adoption of IFRS (IFRSxBONUS).

To capture the strength of the monitoring system in place to curb managerial opportunism we include in the model, an indicator variable highlighting acquisitions in which the acquiring firm uses a Big 4 auditor in the first financial year in which the target firm is consolidated, zero otherwise (BIG4). As indicated above, we include bidding firm leverage in the model. This variable also controls for the monitoring role of debt holders. ${ }^{7}$ We also include in the regression the relative size of the target to the bidder measured using the natural logarithm of the target firm to acquiring firm market capitalisation two months before the takeover announcement (RELSIZE).

To control for takeover characteristics we include four variables in model (1). First, we control for the equity ownership of the bidder in the target at the date of the takeover announcement (TOEHOLD). We also identify whether the takeover offer is friendly. Friendly takeovers are denoted in the regression using a binary variable coded as one when the initial recommendation of the target firm board is takeover acceptance (FRIENDLY). To capture synergies arising from the acquisition we control for the takeover premium and industry of the target and bidding firms. The takeover premium (PREMIUM) is calculated as the offer price

\footnotetext{
${ }^{7}$ We use the acquiring firm leverage ratio the year before the acquisition to exclude the effects of the takeover on leverage after the acquisition. Results are unchanged if we use leverage in the first year the target firm is consolidated.
} 
minus the target share price two months prior to the takeover announcement, divided by the price two months prior to the takeover announcement. We control for target and bidding firm pairs in the same industry (using two-digit GICS codes) by including an indicator variable set equal to one in such takeovers (SAMEIND). The consideration form used by the bidding firm is controlled through the use of an indicator variable denoting takeovers in which the payment form is completely cash, zero otherwise (PAYCASH).

We also control for the economic characteristics of the target and bidding firms. First, we include the amount of the existing goodwill on the target firm balance sheet $\left(T \_G W_{-} D V\right)$. Goodwill already recorded by the target firm is expected to remain part of the unidentifiable assets of the combined group and as a result should be positively associated with the percentage of the purchase price allocated to goodwill. As the amount allocated to goodwill is determined after adjusting the fair values of other target firm assets we include controls for the target firm's net property plant and equipment $\left(T_{-} P P E_{-} D V\right)$ and recognised identifiable intangible assets (T_IIA_DV). These three variables are extracted from the target firm financial statements for the financial year prior to the takeover and are scaled by deal value. If the difference between the purchase consideration and the book value of target firm assets is recorded firstly against already recognised assets then there is expected to be a negative association between $T \_P P E \_D V$ and $T \_I I A \_D V$ and recorded goodwill. To capture the growth potential of the target firm, we control for the target firm's market to book ratio calculated two months before the takeover announcement $\left(T_{-} M B\right) .{ }^{8}$ Finally, we proxy bidding firm overvaluation using the market to book ratio $\left(B \_M B\right)$ also measured two months before the takeover announcement.

We control for industry fixed effects in the estimation of model (1) through the use of indicator variables based on the target firm two digit GICS code. In the interest of brevity we do not report the results on these variables. Standard errors are also clustered by the year of takeover announcement to correct for potential serial correlation. Appendix 1 provides a summary of the definitions of all variables used in this study.

\section{Sample and data}

\footnotetext{
${ }^{8}$ The market value two months before the takeover announcement is used as there is often a run-up in target share price leading up to the takeover announcement (Schwert 1996). In additional tests we also include the target firm sales growth in the two years leading up to the takeover announcement (T_GROWTH) as an additional variable in the model.
} 
The Connect 4 Mergers and Acquisitions database is used to identify all takeovers announced for Australian Securities Exchange (ASX) listed targets between 1998 and 2012. This search identified 1,239 takeovers. Since this study is investigating the amount allocated to goodwill after successful acquisitions it is necessary to exclude 394 unsuccessful takeovers. Also, as the amount of goodwill is collected from the financial statements of the successful bidder we delete 346 takeovers in which the bidding firm is not listed on the ASX. For a similar reason it is also necessary to eliminate 20 takeovers in which the acquiring firm is delisted from the ASX prior to the dissemination of their financial statements post- acquisition. Due to missing data needed to estimate the regression model we remove 171 observations from the sample. This sample collection process is summarised in Table 1.

\section{INSERT TABLE 1 HERE}

Panel A of Table 2 presents the temporal distribution of the sample. The two years with the highest proportion of takeovers are 2006 and 2000 with respectively $10.4 \%$ and $9.7 \%$ of successful takeovers occurring in these two years. The lowest number of takeovers occurs in the first year of the sample (i.e., 1998).

\section{INSERT TABLE 2 HERE}

The breakdown of the sample by target and acquiring firm industry is shown in Panel $\mathrm{B}$ of Table 2. Industrial classification is based on target and acquiring firm two digit GICS codes. Approximately $30 \%$ of target and bidding firms are from the materials sector. The second largest sector included in our sample is financial firms (approximately 16\%), followed by takeovers in the consumer discretionary industry (between 13-14\%). The industry sector with the lowest representation in the sample is utilities. We control for industry fixed effects in the estimation of our regression models using indicator variables for target firm two digit GICS codes.

We collect the amount of the purchase price allocated to goodwill for each acquisition by firstly downloading the acquiring firm's financial statements subsequent to the takeover from the Morningstar DatAnalysis database. We then read through the notes to the accounts to 
determine the first year in which the target firm is consolidated. For this financial year we hand collect the amount (if any) of the purchase price allocated to goodwill and identifiable intangible assets. ${ }^{9}$ We also hand collect for that year details of the acquiring firm auditor and whether the financial statements are prepared using IFRS. The target firm takeover documents lodged with the ASX are used to manually collect information on the recommendation of the target firm board to shareholders. In a similar fashion, we collect from the bidding firm documents lodged with the ASX details of: the bidding firm toehold, the initial offer price and the method of payment. The Morningstar DatAnalysis database is used as the source of both the target and bidding firm takeover documents.

Share price information used to calculate takeover premiums, relative size and market to book ratios are extracted from the Core Research Database maintained by SIRCA. Accounting information needed to calculate bidding firm leverage, target firm asset values (i.e, goodwill, identifiable intangible assets and property plant and equipment) and the book values of equity for the target and acquiring firm are obtained from the financial statements released for the year prior to the takeover announcement. We determine the existence of an accounting based bonus plan for the bidding firm CEO by reading through the directors' report included in the bidding firm's annual report in the year prior to the takeover announcement.

Table 3 presents descriptive statistics for the variables included in the regression model.

\section{INSERT TABLE 3 HERE}

Panel A of Table 3 presents descriptive statistics for each variable after partitioning the firms into those that record no goodwill and those that report positive goodwill. The results indicate that CEO bonuses (BONUS (\$000)) are significantly higher for firms which report a non-zero balance of goodwill. This preliminary evidence is consistent with the opportunistic argument whereby managers use their discretion to recognise more goodwill. The results also indicate that firms which record goodwill have higher leverage $\left(B \_L E V\right)$ and are more likely to engage Big 4 auditors (BIG4) consistent with a monitoring explanation. Firms recognising goodwill also report larger amounts of acquired identifiable intangible assets (IIA $(\$ m))$, and are more likely to use cash as the method of payment (PAYCASH). Surprisingly, the descriptive

\footnotetext{
${ }^{9}$ Due to a lack of disclosure we are unable to further partition identifiable intangibles into separate categories (e.g., brand names, patents etc.).
} 
results show that goodwill is less likely to be recorded when the target and the acquiring firm operate in the same industry (SAMEIND). The findings also show that there is no statistical difference in the proportion of firms with a non-zero balance of goodwill after the adoption of IFRS $($ IFRS $) .^{10}$

Panel B of Table 3 presents the mean for each of the variables after partitioning the sample by whether the takeover is first consolidated before or after the adoption of IFRS. A comparison of variables before and after the adoption of IFRS shows that the percentage of the purchase price allocated to goodwill is higher after the adoption of IFRS, although the difference is insignificant. A number of the other variables show significant changes after the adoption of IFRS. The results show that the target and bidding firm market-to-book ratios ( $T \_M B$ and $\left.B \_M B\right)$ and the use of friendly acquisitions (FRIENDLY) are significantly higher in the post- IFRS sub-sample. ${ }^{11}$ In contrast, after the adoption of IFRS we find a significant decrease in the ownership stake of the bidder in the target firm (TOEHOLD), and acquisitions in which the target and bidder are in the same industry (SAMEIND).

Panel C of Table 3 presents descriptive statistics for the variables in model (1) partitioned by whether the CEO of the acquiring firm has an accounting based compensation plan in place for the year prior to the takeover. There is no significant difference in the proportion of the purchase price allocated to goodwill and identifiable intangible assets for firms with and without a CEO accounting based bonus plan in place. We find that acquiring firms which use accounting based bonus plans are more likely to offer cash payment (PAYCASH) and engage Big 4 audit firms (BIG4). The greater use of Big 4 auditors by these firms is suggestive of larger firms remunerating their CEO with accounting based bonus schemes.

\footnotetext{
${ }^{10}$ A year-by-year breakdown of the proportion of acquiring firms which record a zero balance of goodwill shows that between 1998 and 2007 only two years have 50\% or more firms recording zero goodwill (i.e., 1999 and 2002). In contrast, between 2008 and 2012, in each year, more than 50\% of firms recording a nil balance of goodwill. As presented in Panel A Table 3 however, the association between the proportion of firms with nil goodwill and the adoption of IFRS is not statistically significant.

${ }^{11}$ The significant increase in friendly acquisitions after the adoption of IFRS is potentially suggestive of managers increasing acquisition activity after the adoption of IFRS to possibly take advantage of the change in accounting rules for goodwill amortisation. Further examination for instance, reveals that the percentage of friendly acquisitions in our sample was: 73\% in 2004; $96 \%$ in 2005 and $84 \%$ in 2006. Although, this may suggest that managers potentially timed acquisitions to take place after the adoption of IFRS it is problematic for us to ascertain whether this is the case. We leave this question for investigation in future research.
} 
The descriptive statistics presented in Table 3 show the presence of significant outliers. As a result we winsorise the top and bottom $1 \%$ of the continuous variables when estimating model (1).

Table 4 presents a Pearson correlation matrix for the variables included in the regression model.

\section{INSERT TABLE 4 HERE}

We find a significant positive correlation between bidding firm leverage $\left(B \_L E V\right)$ and the percentage allocated to goodwill. Consistent with predictions there is a significant negative association between the acquiring firm toehold (TOEHOLD) and the amount allocated to goodwill. Also in line with expectations, there is a significant positive correlation between takeover premiums (PREMIUM) and the percentage of the purchase price allocated to goodwill. As predicted, the results show a significant positive correlation between the proportion of the purchase price allocated to goodwill and the pre- takeover goodwill of the target firm $\left(T_{-} G W_{-} D V\right)$. The positive correlation between pre-takeover target firm PPE $\left(T \_P P E \_D V\right)$ and the proportion allocated to goodwill is however unexpected. The size of the correlations between the independent variables included in the model (1) indicates that multicollinearity is unlikely to be a concern with the estimation of the regression model. This is confirmed by VIF diagnostics testing conducted after estimating the regression model.

\section{Results}

\subsection{Purchase price allocated to goodwill}

The results of estimating regression model (1) examining the factors which influence the percentage of the purchase price allocated to goodwill are presented in Table 5.

\section{INSERT TABLE 5 HERE}

The first six independent variables are proxies for opportunism and monitoring. The indicator variable denoting takeovers consolidated using IFRS is positive and significant indicating that the change from goodwill amortisation to goodwill impairment increased the proportion of the purchase price allocated to goodwill. This finding indicates that firms have 
taken advantage of the new accounting regime to allocate more of the purchase price to a nonamortised asset which results in higher reported earnings. The results also show that acquiring firms with higher pre-acquisition leverage $\left(B \_L E V\right)$ are more likely to allocate a greater percentage of the purchase price to goodwill. ${ }^{12}$ This finding is inconsistent with an opportunism explanation but could be suggestive of the increased monitoring of debt holders in financial reporting. Greater monitoring of borrowers may be more likely in Australia due to the prevalence of corporate private lending from banks as opposed to public debt issues (Cotter, 1998). ${ }^{13}$

The result on BONUS is positive and significant, but the interaction of this variable with IFRS is insignificant. As such, our results suggest that bidding firms which compensate their CEO with accounting based remuneration allocate a greater proportion of the purchase price to goodwill and this association was unchanged after Australia's adoption of IFRS. A possible explanation of this finding is that before IFRS adoption goodwill was amortised over a maximum period of 20 years. As this amortisation period likely exceeds the useful life employed for other tangible assets, allocating a greater amount of the purchase price to goodwill is likely to minimise depreciation and amortisation charges and maximise firm profit. Turning to the variables which proxy for firm monitoring we find no association between Big 4 audit firms (BIG4) and the relative size of the target to the bidder (RELSIZE) and the amount of the deal value allocated to goodwill. ${ }^{14}$

$\mathrm{H}_{3 a}$ predicts that due to lower information asymmetry the proportion of the purchase price recorded as goodwill is lower in friendly acquisitions and acquisitions in which the bidding firm has a higher toehold. The results, however, are inconsistent with expectations with an insignificant coefficient on both TOEHOLD and FRIENDLY. We find a significant positive association between takeover premiums (PREMIUM) and the percentage of the purchase price allocated to goodwill. This result is unsurprising because as discussed by Johnson and Petrone

\footnotetext{
12 This result is inconsistent with prior studies as firms with higher leverage would be expected to allocate a greater proportion of the purchase price to tangible assets to allow the firm to loosen any debt covenants that are defined excluding intangible assets. Our results are also inconsistent with Wong and Wong (2001) who argue that firms with low leverage have a better investment opportunity set and as a result allocate a greater amount of the purchase price to goodwill.

${ }^{13}$ As a robustness test we re-estimate our regression model using the debt-to-assets ratio as an alternative measure of bidding firm leverage. The coefficient on this revised leverage measure is positive and significant at the $10 \%$ level. The conclusions from our other results remain unchanged.

${ }^{14} \mathrm{We}$ also estimate the regression replacing the relative size variable with separate variables for the acquiring and target firm size measured using the natural logarithm of the market capitalisation of each firm two months prior to the takeover announcement. Both the target and bidder size variables in this alternative regression are insignificant and the other results remain unchanged.
} 
(1998), goodwill is calculated as the residual between the purchase price and the fair value of the net assets acquired. Since a higher premium mechanically increases the size of the purchase price this is likely to result in a higher amount being recorded as the residual difference (i.e., goodwill). The coefficient on SAMEIND is significant but the negative sign is counter to our expectations. As synergies would be predicted to be higher in takeovers amongst firms in the same industry it was expected that these takeovers would result in a higher amount being allocated to goodwill.

We find that goodwill is more likely to be recorded when the method of payment is cash (PAYCASH). As acquiring firms which offer equity have flexibility in regards to the value attributed to the purchase consideration our findings suggest that acquiring firms use this flexibility to record less goodwill. An alternative explanation is that the characteristics of target firms acquired with cash are associated with a higher level of purchased goodwill. Interestingly, our findings are inconsistent with prior studies which document greater goodwill and goodwill impairment when equity is used as payment consideration (Hayn and Hughes 2006; Gu and Lev 2011 and Li et al., 2011).

In terms of the economic characteristics of the target firm, we find only the coefficient on $T \_G W \_D V$ to be significant in the predicted direction with the results indicating a higher amount is allocated to goodwill when the target firm has greater pre-existing goodwill. Surprisingly, the target and bidder firm market-to-book ratios are insignificant in the regression results.

\subsection{Additional analysis}

\subsubsection{Self-selection bias in CEO compensation structure}

Accounting and finance researchers are frequently confronted in their studies with issues relating to selection bias (Tucker 2010; Lennox et al., 2012). This self-selection issue occurs because firm decisions are typically chosen from a number of different courses of action and the researcher is usually unable to observe all the factors that drive the chosen outcome. As highlighted by Maddala, (1991), if firm selection occurs non-randomly then regression analysis may lead to biased coefficients due to omitted correlated variables.

A commonly used approach to control for selection bias is the Heckman (1979) twostage approach. This method requires the estimation of a first-stage probit regression which models the selection choice of interest. This first-stage regression estimates a bias correction 
term (i.e., the inverse Mills ratio) which is then included as an additional variable in the second stage regression. As indicated by Lennox et al. (2012) the use of the Heckman (1979) method requires the identification of an exclusion variable which is included in the first-stage probit model but which can be validly omitted from the second-stage regression.

The results presented above show that acquiring firms which compensate their CEO using an accounting based bonus plan allocate a greater amount of the purchase price to goodwill. As discussed by Shalev et al. (2013), this relationship is subject to endogeneity concerns as compensation structure and purchase price allocations may be driven by the same underlying variables. For instance, Smith and Watts (1992) argue that the use of accountingbased compensation may be negatively related to firm growth options. Simultaneously, Wong and Wong (2001) argue that a firm's investment opportunity set is also associated with a firm's purchase price allocation to goodwill. Shalev et al. (2013) also argue that a CEO may alter their compensation structure to ensure that greater compensation is tied to accounting earnings and then manipulate the amount allocated to goodwill.

Due to the difficulty associated with identifying an exclusion variable to model the choice of the use of accounting based-bonus plans we do not conduct a Heckman (1979) twostage approach. Instead we partially address the self-selection concern by partitioning our sample into those firms with and without a CEO accounting based bonus plan and estimate model (1) separately for each of these two groups. These results are presented in Table 6.

\section{INSERT TABLE 6 HERE}

An analysis of the findings in Table 6 indicates a contrasting effect of the adoption of IFRS on the allocation of the purchase price to goodwill for the two groups. For firms with an accounting based bonus plan the IFRS indicator variable is insignificant suggesting that the change in accounting requirements had no impact on the decision to recognise goodwill. Combined with the results documented in Table 5, this suggests CEOs which have an accounting based bonus-plan allocated an additional amount to goodwill both before and after IFRS adoption. In contrast, for firms without an accounting based bonus plan the IFRS indicator variable is positive and significant. As such, these firms allocated an additional amount to goodwill to report higher earnings only after IFRS adoption. 
Interestingly, the unexpected finding on bidder leverage is only significant for firms which offer their CEO an accounting based bonus plan. This is suggestive of heightened monitoring of creditors for these firms. There is also now some evidence consistent with $\mathrm{H}_{3 \mathrm{a}}$ as the bidding firm toehold is now negative for bidding firms whose CEOs receive an accounting based bonus. We also find a positive association between cash payment and acquired goodwill when the CEO receives a bonus. After partitioning the sample the results continue to suggest that the target firm economic characteristics generally do not influence the allocation of the purchase price to goodwill with the exception of $T_{-} G W_{-} D V$.

\subsubsection{Allocation of the purchase price to identifiable intangible assets}

The adoption of IFRS in Australia in 2005 also led to changes in the accounting for identifiable intangible assets. Pre-IFRS the accounting for identifiable intangible assets was largely unregulated and management had discretion to recognise both purchased and internally generated identifiable intangible assets. ${ }^{15}$ Identifiable intangible assets acquired as part of a business combination were required to be recorded at their fair value (AASB 1015 Acquisition of Assets). Furthermore, in the absence of accounting guidance, management had discretion as to whether intangible assets that were recorded (including those acquired in a business combination) were amortised systemically to the income statement. ${ }^{16}$ Post-IFRS, AASB 138 Intangible Assets prohibited the recognition of internally generated intangible assets. Additionally, it requires identifiable intangible assets to be amortised if such assets have a finite life and to be tested annually for impairment tested if the asset's life is considered indefinite.

Wyatt (2005) examines the factors which are associated with the recording of intangible assets in Australia's unregulated environment. The results indicate that the underlying economic characteristics of the firm, rather than opportunism, explain management's decision to record intangible assets. A number of more recent studies examine the impact of the adoption of IFRS on intangible assets. For example, Chalmers et al. (2008) find evidence consistent with IFRS adoption in Australia improving the value relevance of goodwill. In contrast, the value relevance of other intangibles is found to be higher using the pre- IFRS accounting standards. Chalmers et al. (2011b) examine if the association between goodwill charges to the income

\footnotetext{
${ }^{15}$ Prior to the adoption of IFRS there was an accounting standard regulating the manner of accounting for research and development (AASB 1011 Accounting for Research and Development). This standard allowed the capitalisation of research and development only if future economic benefits were expected to exceed costs beyond a reasonable doubt.

${ }^{16}$ Wyatt et al. (2001) present descriptive evidence on the methods used to account for identifiable intangibles prior to the adoption of IFRS.
} 
statement and a firm's investment opportunity set changed after Australia's adoption of IFRS. They show that goodwill charges have a higher association with a firm's investment opportunity set only in the goodwill impairment regime (i.e., post- IFRS). Meanwhile Chalmers et al. (2012) find that after the adoption of IFRS, the size and dispersion of analyst forecast error is more negatively associated with reported intangible assets than pre- IFRS, with this result being driven by goodwill.

The above discussion highlights that managers were provided broad discretion over whether to amortise identifiable intangible assets acquired in a business combination before the adoption of IFRS. If firms acted opportunistically they could maximise post- acquisition profits by over allocating the purchase price to such assets and not subsequently amortising them. Furthermore, this approach would minimise the proportion of the purchase price allocated to goodwill which was subject to periodic amortisation. After the adoption of IFRS, the necessity to amortise intangible assets was dependent on whether managers determined that these assets had a finite or indefinite life. In consequence, the change in accounting requirements for intangible assets upon adopting IFRS does not have a conclusive impact on post- acquisition profit as firms can continue to avoid amortisation by classifying these assets as having an indefinite life.

To provide evidence on whether the change in the accounting requirements for intangible assets upon the adoption of IFRS influenced the allocation of the purchase price to identifiable intangible assets we re-estimate a modified version of model (1). This alternative model employs as the dependent variable the proportion of the purchase price allocated to identifiable intangible assets $\left(I I A \_D V\right)$. The independent variables are consistent with those in the original model. The results of estimating this regression (not tabulated) show that the IFRS indicator variable has an insignificant coefficient suggesting that the adoption of IFRS did not influence the percentage of the purchase price which is allocated to identifiable intangible assets. The other variables capturing opportunism such as the CEO bonus indicator variable and bidding firm leverage are also insignificant. The results indicate that a lower toehold; lower target PPE and higher target existing identifiable intangible assets increase the percentage of the purchase price allocated to identifiable intangibles.

\subsubsection{Multiple bidders}

Prior studies (e.g., Ruback 1983 and Giliberto and Varaiya 1989), document that acquiring firms tend to overpay when there are competing bids, consistent with there being a 
'winner's curse.' We investigate whether the presence of competing bids impacts on the amount of the purchase price allocated to goodwill. To control for competing bidders, we create an indicator variable set to equal to one if there is at least one competing bidder, zero otherwise. We do not find an association between acquired goodwill and the presence of competing bidders. The conclusions from our other results remain unchanged.

\subsubsection{Growth potential of the target firm}

To ensure that our findings are not driven by the target's growth potential, we re-run the tests including an additional variable $T_{-} G R O W T H$. As we are unable to access actual growth forecasts for our sample period we use the target firms' growth in the two years preceding the acquisition as a proxy for future growth. The Australian Bureau of Statistics provides growth forecast data up until 2002 and the IBES database contain growth forecast data from 2003 onwards. We do not find an association between T_GROWTH and acquired goodwill suggesting that acquired goodwill does not seem to capture the future growth potential of the target firm.

\section{Conclusion}

The accounting for purchased goodwill is controversial and has been subject to a substantial amount of previous research. An area that has received little attention in prior studies are the factors which determine the amount recorded as goodwill at the time the target firm is first consolidated into the bidding firm's financial statements. This study addresses this void in the literature. Our results tend to support the argument that the allocation of the purchase price to goodwill is opportunistic and suggest that the amount allocated to goodwill does not appear to reflect synergy potential. A possible area for future research is to further refine these tests using better measures of target firm growth potential and synergies.

Consistent with firms undertaking their purchase price allocation opportunistically, we find that the amount allocated to goodwill increases after the adoption of IFRS when goodwill is no longer amortised. Thus, it appears that bidding firms took advantage of this change in accounting requirements to allocate more to goodwill to increase reported profitability postacquisition. We also document a positive association between the amount allocated to goodwill and the use of accounting based CEO bonus plans by acquiring firms. This association was unchanged by the adoption of IFRS. Therefore, it appears that CEOs that are remunerated 
partially based on accounting results have consistently allocated more to goodwill after an acquisition. A possible explanation of this finding is that pre- IFRS an over-allocation of the purchase price to goodwill increases reported profit as the life of other tangible assets are likely to be shorter than the 20 year life used for amortising goodwill. We also show that firms offering cash as payment are more likely to record goodwill.

We also find evidence that more leveraged acquiring firms allocate a higher amount to goodwill. This result is inconsistent with opportunism. Our results, however, show no association between the use of Big 4 auditors and the amount allocated to goodwill. Supporting the results in earlier studies we find that a higher takeover premium results in the recording of additional goodwill. This result is unsurprising as any additional premium flows through to the amount recorded as goodwill, given that goodwill is calculated as the difference between the purchase price and the target firm identifiable net assets.

Collectively, our findings highlight that managers use their discretion when conducting purchase price allocations following a business combination. Our results are likely to be of interest to accounting standard setters when debating how to account for goodwill postacquisition, as our findings suggests firms have opportunistically increased their allocation of the purchase price to goodwill after IFRS adoption. Future research could shed further light on other contractual and non-contractual incentives to over or under allocate the purchase price in acquisitions to goodwill (e.g. earnings volatility or capital raising). In addition, future studies might examine whether subsequent goodwill impairment decisions are associated with factors found to be associated with the recognition of goodwill in this study. 


\section{References}

Aboody, D., R. Kazsnik, and M. Williams, 2000, Purchase versus Pooling in Stock-for-Stock Acquisitions: Why Do Firms Care? Journal of Accounting and Economics 29, 261-286.

Abu Ghazaleh, N., O. Al-Hares, and A. Haddad, 2012, The Value Relevance of goodwill impairments: UK Evidence. International Journal of Economics \& Finance 4, 206-216.

Accounting Standards Committee, 1984, Statement of Standard Accounting Practice 22: Accounting for Goodwill.

Anderson, D., and I. Zimmer, 1992, Reactions to regulation of accounting for goodwill. Accounting and Finance 32, 27-50.

Armstrong, C., W. Guay, and J. Weber, 2010 The role of information and financial reporting in corporate governance and debt contracting. Journal of Accounting and Economics 50, 179234.

Australian Accounting Standards Board, 1996, AASB 1013, Accounting for goodwill.

Australian Accounting Standards Board, 2010, AASB 136, Impairment of Assets.

Australian Accounting Standards Board, 2009, AASB 3, Business Combinations.

Ayers, B., C. Lefanowicz, and J. Robinson, 2002 Do firms purchase the pooling method? Review of Accounting Studies 7, 5-32.

Bargeron, L., F. Schlingemann, R. Stulz, and C. Zutter 2008, Why do private acquirers pay so little compared to public acquirers? Journal of Financial Economics 89, 375-390.

Barth, M. E., and G. Clinch, 1996, International accounting differences and their relation to share prices: evidence from U.K., Australian, and Canadian firms. Contemporary Accounting Research 13, 135-170.

Barth, M., W. Landsman, and M. Lang, 2008, International accounting standards and accounting quality. Journal of Accounting Research 46, 467-498.

Beatty, A., and J. Weber, 2006, Accounting discretion in fair value estimates: An examination of SFAS 142 goodwill impairments. Journal of Accounting Research 44, 257288.

Bellamy, D., and W. Lewin, 1992, Corporate takeovers, method of payment, and bidding firms' shareholder returns: Australian evidence, Asia Pacific Journal of Management 9, 137149.

Bens, D., W. Heltzer, and B. Segal, 2011, The information content of goodwill impairments under SFAS 142, Journal of Accounting and Public Policy 26, 527-555.

Bryer, R., 1995, A political economy of SSAP22: Accounting for goodwill, British Accounting Review 27, 283-310. 
Bugeja, M., and N. Gallery, 2006, Is older goodwill value relevant? Accounting and Finance 46, 519-535.

Bugeja, M., and T. Walter, 1995, An empirical analysis of some determinants of the target shareholder premium in takeovers, Accounting and Finance 35, 33-60.

Chalmers, K., J. Godfrey, and J. Webster, 2011, Does a goodwill impairment regime better reflect the underlying economic attributes of goodwill? Accounting and Finance 51, 634-660.

Chauvin, K., and M. Hirschey, 1994, Goodwill, profitability, and the market value of the firm, Journal of Accounting and Public Policy 13, 159-180.

Chalmers, K., G. Clinch, and J. Godfrey, 2011, Changes in value relevance of accounting information upon IFRS adoption: Evidence from Australia. Australian Journal of Management 36, 151-173.

Chen, C., M. Kohlbeck, and T. Warfield, 2004, Goodwill valuation effects of the initial adoption of SFAS 142. Working paper.

Clinch, G., 1995, Capital markets research and the goodwill debate. Australian Accounting Review 5, 22-30.

Comiskey, E., J. Clarke, and C. Mulford, 2010, Is negative goodwill valued by investors? Accounting Horizons 24, 333-353.

Copeland, R., and J. Wojdak, 1969, Income manipulation and the purchase-pooling choice. Journal of Accounting Research 7, 188-195.

Cotter, J., 1998, Utilisation and restrictiveness of covenants in Australian private debt contracts. Accounting and Finance 38, 181-196.

Cotter, J., A. Tarca, and M. Wee, 2012, IFRS adoption and analysts' earnings forecasts: Australian evidence. Accounting and Finance 52, 395-419.

Dahmash, F., R. Durand, and J. Watson, 2009, The value relevance and reliability of reported goodwill and identifiable intangible assets. British Accounting Review 41, 120-137.

Daske, H., L. Hail, C. Leuz, and R. Verdi, 2008, Mandatory IFRS adoption around the world: Early evidence on the economic consequences. Journal of Accounting Research 46, 10851142 .

Fields, T., T. Lys, and L. Vincent, 2001, Empirical research on accounting choice. Journal of Accounting and Economics 31, 255-307.

Financial Accounting Standards Board (FASB), 2001, "Statement of Financial Accounting Standards No. 142, Goodwill and Other Intangibles.' Stamford, CT: FASB.No. 142, Goodwill and Other Intangibles.' Stamford, CT: FASB.

Francis, J., D. Hanna and L. Vincent, 1996, Causes and effects of discretionary asset writeoffs. Journal of Accounting Research 34, 117-134. 
Francis, J., and M. D. Yu, 2009, Big 4 office size and audit quality. The Accounting Review $84,1521-1552$.

Gagnon, J., 1967, Purchase versus pooling of interests: The search for a predictor. Journal of Accounting Research 5, 187-204.

Gibson, R., and J. Francis, 1975, Accounting for goodwill - A study in permissiveness. Abacus $11,167-171$.

Godfrey, J., and P.-S. Koh, 2001, The relevance to firm valuation of capitalising intangible assets in total and by category. Australian Accounting Review 11, 39-48.

Gore, P., F. Taib, and P. Taylor, 2000, Accounting for goodwill: an examination of factors influencing management preferences. Accounting and Business Research 30, 213-225.

Godfrey, J., and P.S. Koh, 2009, Goodwill impairment as a reflection of investment opportunities. Accounting and Finance 49, 117-140.

Grinyer, J., A. Russell, and M. Walker, 1991, Managerial choices in the valuation of acquired goodwill in the UK. Accounting and Business Research 85, 51-55.

Gu, F., and B. Lev, 2011, Overpriced shares, ill-advised acquisitions and goodwill impairment. The Accounting Review 86, 1995-2022.

Hayn, C., and P. Hughes, 2006, Leading indicators of goodwill impairment. Journal of Accounting and Public Policy, 223-265.

Heckman, J., 1979, Sample selection bias as a specification error. Econometrica 47, 153-161.

Henning, S. L., B. L. Lewis, and W. H. Shaw, 2000, Valuation of the components of purchased goodwill. Journal of Accounting Research 38, 375-386.

Henry, D., 2004, Corporate governance and ownership structure of target companies and the outcome of takeovers. Pacific Basin Finance Journal 12, 419-444.

Hirschey, M., and V. Richardson, 2002, Information content of accounting goodwill numbers. Journal of Accounting and Public Policy 21, 173-191.

Holthausen, R. W., and R. L. Watts, 2001, The relevance of the value-relevance literature for financial accounting standard setting. Journal of Accounting and Economics 31, 3-75.

Horton, J., G. Serafeim, and I. Serafeim, 2013, Does mandatory IFRS adoption improve the information environment? Contemporary Accounting Research 30, 388-423.

Jennings, R., J. Robinson, R. B. Thompson, and L. Duvall, 1996, The relation between accounting goodwill numbers and equity values. Journal of Business Finance and Accounting $23,513-533$.

Johnson, L., and K. Petrone, 1998, Is goodwill an asset? Accounting Horizons 12, 293-303.

Lai, C., Y. Shan, and S. Taylor, 2013, Costs of mandatory international financial reporting standards. Australian Journal of Management 38, 491-521. 
Le, H., and E. Schultz, 2007, Toeholds and the Bidder Shareholder Wealth Effects of Takeover Announcements, Australian Journal of Management 32, 315-344.

Leftwich, R., 1983, Accounting information in private markets: Evidence from private lending agreements. Accounting Review 58, 23-42.

Lennox, C., J. Francis, and Z. Wang, 2012, Selection models in Accounting research. The Accounting Review 87, 589-616.

Li, Z., Z. Shroff, R. Venkataraman, and I. Zhang, 2011, Causes and consequences of goodwill impairment losses. Review of Accounting Studies 16, 745-778.

Louis, H., 2005, Acquirers' abnormal returns and the non-Big 4 auditor clientele effect. Journal of Accounting and Economics 40, 75-99.

Maddala, G., 1991, A perspective on the use of limited-dependent and qualitative variables models in accounting research. The Accounting Review 66, 788-807.

Malmendier, U., and G. Tate, 2008, Who makes acquisitions? CEO overconfidence and the market's reaction. Journal of Financial Economics 89, 20-43.

Mather, P., and G. Peirson, 2006, Financial covenants in the markets for public and private debt. Accounting and Finance 46, 285-307.

Muller, K.A., 1999, An examination of the voluntary recognition of acquired brand names in the United Kingdom. Journal of Accounting and Economics 26, 179-191.

Myers, S., and N. Majluf, 1984, Corporate financing and investment decisions when firms have information that investors do not have. Journal of Financial Economics 13, 187-221.

Nelson, R. H., 1953, The momentum theory of goodwill. The Accounting Review, 491-499.

Ramanna, K., 2008, The implications of unverifiable fair-value accounting: evidence from the political economy of goodwill accounting. Journal of Accounting and Economics 45, 253 281.

Rau, R., and T. Vermaelen, 1998, Glamour, value and the post-acquisition performance of acquiring firms. Journal of Financial Economics 49, 223-253.

Robinson, J., and P. Shane, 1990, Acquisition accounting method and bid premia for target firms. The Accounting Review 65, 25-48.

Roll, R., 1986, The hubris hypothesis of corporate takeovers. Journal of Business 59, 197216.

Savor, P., and Q. Lu, 2009, Do stock mergers create value for acquirers. The Journal of Finance 64, 1061-1097.

Schwert, G.W., 1996, Markup pricing in mergers and acquisitions. Journal of Financial Economics 41, 153-192. 
Shalev, R., I. Zhang, and Y. Zhang, 2013, CEO compensation and fair value accounting: Evidence from purchase price allocation. Journal of Accounting Research 51, 819-854.

Smith, C., and R. Watts, 1992, The investment opportunity set and corporate financing, dividend and compensation policies. Journal of Finanical Economics 32, 263-292.

Stulz, R., 1988, Managerial control of voting rights: financing policies and the market forcorporate control. Journal of Finanical Economics 20, 25-54.

Sudarsanam, S., and A. Mahate, 2003, Glamour acquirers, method of payment and postacquisition performance: the UK evidence. Journal of Business Finance \& Accounting 30, 299-342.

Sudarsanam, S., and G. Sorwar, 2010, Determinants of takeover premium in cash offers: An option pricing approach. Journal of Business Finance \& Accounting 37, 687-714.

Tearney, M.G., 1973, Accounting for goodwill: A realistic approach. Journal of Accountancy $136,41-45$.

Tucker, J., 2010, Selection bias and econometric remedies in Accounting and Finance research. Journal of Accounting Literature 29, 673-698.

Walter, T., 1984, Australian takeovers: Capital market efficiency and shareholder risk and return. Australian Journal of Management 9, 63-118.

Watts, R., and J. Zimmerman, 1990, Positive accounting theory: A ten year perspective. The Accounting Review 65, 131-158.

Wong, J., and N. Wong, 2001, The investment opportunity set and acquired goodwill. Contemporary Accounting Research 18, 173-196. 
Table 1

Sample selection

The sample comprises takeovers announced for ASX listed targets identified from the Connect 4 Mergers and Acquisitions Database.

\begin{tabular}{lc}
\hline Takeovers between 1998 to 2012 & 1,239 \\
Less: Unsuccessful takeover bids & $(394)$ \\
Less: Acquiring firms not listed on the ASX & $(346)$ \\
$\begin{array}{l}\text { Less: Acquiring firms which are delisted post- acquisition prior to } \\
\text { releasing financial statements }\end{array}$ & $(20)$ \\
Less: Takeovers with missing observations to test model (1) & 308 \\
Sample for estimating model (1)
\end{tabular}




\section{Table 2}

\section{Temporal and industry distribution of the sample}

Panel A table shows the yearly distribution of the sample by takeover announcement date. Panel B presents the distribution of the sample by target and bidding firm two digit GICS codes.

\begin{tabular}{llll}
\hline \multicolumn{3}{l}{ Panel A: Sample temporal distribution } & \\
\hline Year takeover & \multicolumn{1}{l}{ No. of } & \% of & Cumulative \% \\
announced & takeovers & sample & \\
\hline 1998 & 5 & 1.62 & 1.62 \\
1999 & 22 & 7.14 & 8.77 \\
2000 & 30 & 9.74 & 18.51 \\
2001 & 25 & 8.12 & 26.62 \\
2002 & 13 & 4.22 & 30.84 \\
2003 & 15 & 4.87 & 35.71 \\
2004 & 26 & 8.44 & 44.16 \\
2005 & 26 & 8.44 & 52.60 \\
2006 & 32 & 10.39 & 62.99 \\
2007 & 29 & 9.42 & 72.44 \\
2008 & 11 & 3.57 & 75.97 \\
2009 & 24 & 7.79 & 83.77 \\
2010 & 19 & 6.17 & 89.94 \\
2011 & 12 & 3.90 & 93.93 \\
2012 & 19 & 6.17 & 100 \\
\hline Total & 308 & 100 & \\
\hline
\end{tabular}

\begin{tabular}{|c|c|c|c|c|}
\hline \multicolumn{5}{|c|}{ Panel B: Sample GICS distribution } \\
\hline \multirow[t]{2}{*}{ Industry } & \multicolumn{2}{|c|}{ Bidder } & \multicolumn{2}{|c|}{ Target } \\
\hline & Number & $\%$ of sample & Number & $\%$ of sample \\
\hline Consumer Discretionary & 46 & 14.94 & 40 & 12.99 \\
\hline Consumer Staples & 22 & 7.14 & 17 & 5.52 \\
\hline Energy & 29 & 9.42 & 25 & 8.12 \\
\hline Financials & 49 & 15.91 & 49 & 15.90 \\
\hline Health Care & 16 & 5.19 & 16 & 5.19 \\
\hline Industrial & 31 & 10.06 & 32 & 10.39 \\
\hline Information Technology & 11 & 3.57 & 17 & 5.52 \\
\hline Materials & 87 & 28.25 & 101 & 32.80 \\
\hline Telecommunication & 12 & 3.90 & 7 & 2.27 \\
\hline Utilities & 5 & 1.62 & 4 & 1.30 \\
\hline Total & 308 & 100 & 308 & 100 \\
\hline
\end{tabular}




\section{Table 3}

\section{Descriptive statistics}

Panel A: This table presents descriptive statistics for the variables included in regression model (1) for bidding firms reporting no goodwill and bidding firms reporting positive goodwill. A test of statistical difference of means for each variable is also shown. A $t$-test is used for continuous variables and a $\chi^{2}$-test for binary variables. All variables are defined in Appendix 1.

\begin{tabular}{|c|c|c|c|c|c|c|c|c|c|}
\hline & \multicolumn{4}{|c|}{ Goodwill = 0 (129 observations) } & \multicolumn{4}{|c|}{ Goodwill >0 (179 observations) } & \multirow{2}{*}{$\begin{array}{l}\text { Statistical } \\
\text { difference }\end{array}$} \\
\hline & Mean & Std. Dev. & Min & Max & Mean & Std. Dev. & Min & Max & \\
\hline$G W(\$ m)$ & 0.000 & 0.000 & 0.000 & 0.000 & 364 & 1,250 & 25,000 & 14000 & $-3.301 * * *$ \\
\hline$G W \_D V$ & 0.000 & 0.000 & 0.000 & 0.000 & 0.563 & 0.472 & 0.000 & 3.227 & $-13.555^{* * *} *$ \\
\hline $\operatorname{IFRS}$ & 0.535 & 0.501 & 0.000 & 1.000 & 0.553 & 0.499 & 0.000 & 1.000 & 0.100 \\
\hline$B \_L E V$ & 1.272 & 4.044 & 0.011 & 41.691 & 2.082 & 3.839 & -3.109 & 22.455 & $-1.786^{*}$ \\
\hline BONUS & 0.442 & 0.499 & 0.000 & 1.000 & 0.631 & 0.484 & 0.000 & 1.000 & $-13.509 * * *$ \\
\hline BONUS $(\$ 000)$ & 219.77 & 775.434 & 0.000 & $8,072.93$ & 366.097 & 653.682 & 0.000 & 3,757 & $-1.792 *$ \\
\hline BIG4 & 0.698 & 0.461 & 0.000 & 1.000 & 0.849 & 0.359 & 0.000 & 1.000 & $10.219 * * *$ \\
\hline RELSIZE & 0.457 & 0.684 & 0.001 & 4.304 & 0.555 & 1.300 & 0.000 & 11.004 & -0.784 \\
\hline TOEHOLD & 0.158 & 0.199 & 0.000 & 0.880 & 0.142 & 0.187 & 0.000 & 0.865 & 0.716 \\
\hline FRIENDLY & 0.868 & 0.340 & 0.000 & 1.000 & 0.838 & 0.369 & 0.000 & 1.000 & 0.539 \\
\hline PREMIUM & 0.462 & 0.984 & -1.000 & 7.341 & 0.451 & 2.459 & -0.969 & 31.500 & 0.049 \\
\hline SAMEIND & 0.698 & 0.461 & 0.000 & 1.000 & 0.575 & 0.496 & 0.000 & 1.000 & $4.789 * *$ \\
\hline PAYCASH & 0.217 & 0.414 & 0.000 & 1.000 & 0.413 & 0.494 & 0.000 & 1.000 & $13.050 * * *$ \\
\hline$T_{-} G W_{-} D V$ & 0.078 & 0.321 & 0.000 & 2.820 & 0.162 & 0.604 & 0.000 & 7.749 & -1.444 \\
\hline$T T_{-} P P E \_D V$ & 0.466 & 1.646 & 0.000 & 13.658 & 0.412 & 1.428 & 0.000 & 15.876 & 0.306 \\
\hline$T \_I I A \_D V$ & 0.047 & 0.183 & 0.000 & 1.691 & 0.087 & 0.194 & 0.000 & 1.202 & $-1.843^{*}$ \\
\hline$T_{-} M B$ & 2.964 & 5.306 & -0.171 & 36.776 & 2.349 & 2.816 & -0.171 & 15.969 & 1.315 \\
\hline$B \_M B$ & 2.940 & 4.657 & 0.210 & 42.690 & 3.213 & 5.008 & 0.180 & 42.690 & -0.487 \\
\hline$I I A(\$ m)$ & 15.3 & 51.4 & 0.000 & 404 & 127 & 464 & 0.000 & 4,300 & $-2.720 * * *$ \\
\hline$I I A \_D V$ & 0.143 & 0.361 & 0.000 & 1.862 & 0.148 & 0.258 & 0.000 & 1.313 & -0.144 \\
\hline
\end{tabular}

* $\quad$ Significant at the 1\% level; ** significant at the 5\% level; *** significant at the $10 \%$ level 
Table 3

\section{Descriptive statistics}

Panel B: This table presents descriptive statistics for the variables included in regression model (1) pre- and post- IFRS adoption (Panel B). A test of statistical difference of means before and after the adoption of IFRS for each variable is also shown. A $t$-test is used for continuous variables and a $\chi^{2}$-test for binary variables. All variables are defined in Appendix 1.

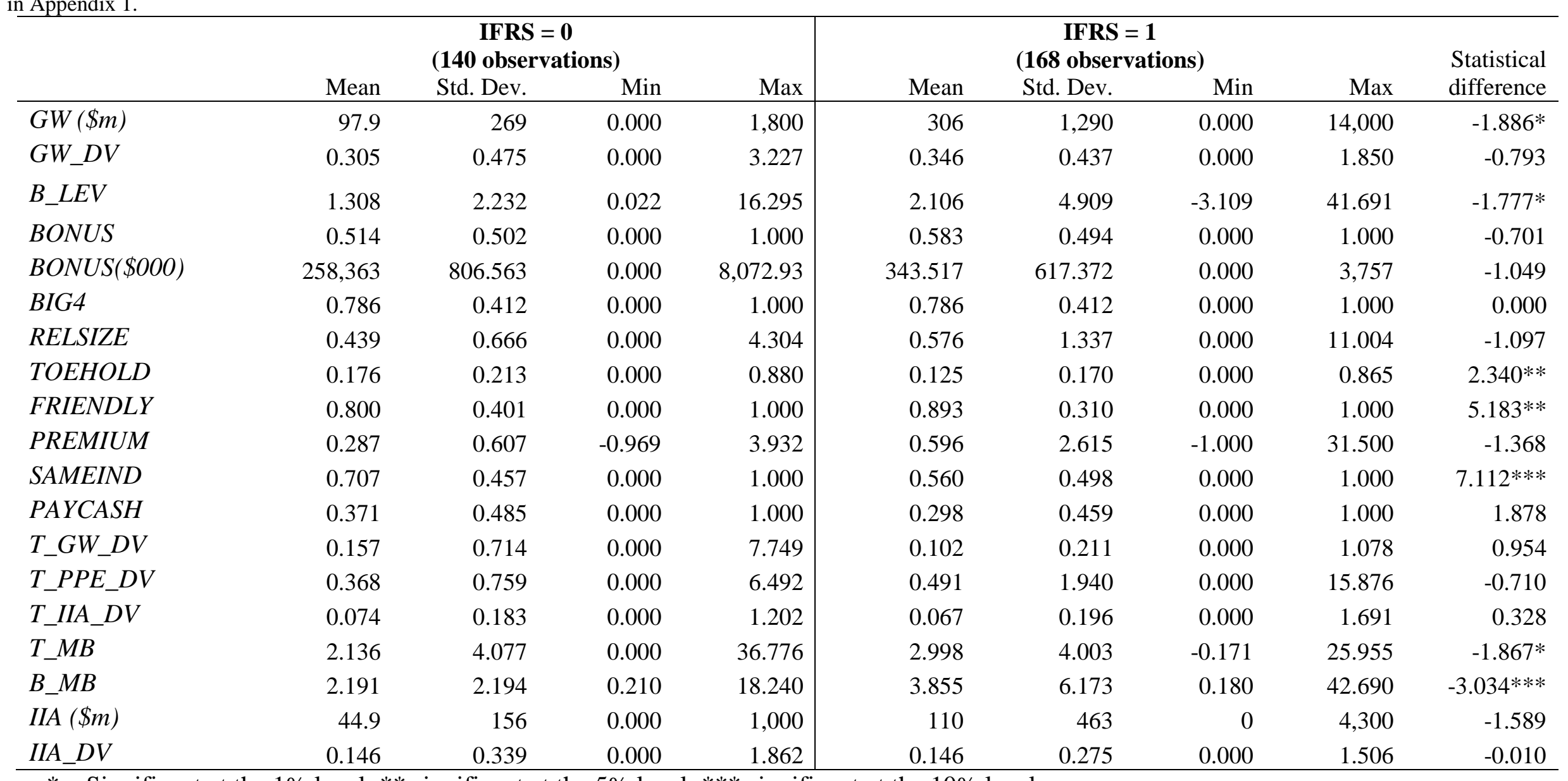

* $\quad$ Significant at the $1 \%$ level; ** significant at the $5 \%$ level; *** significant at the $10 \%$ level 
Table 3

\section{Descriptive statistics}

Panel C: This table presents descriptive statistics for the variables included in regression model (1) for bidding firms with and without an accounting based CEO bonus plan in place. A test of statistical difference of means for firms with and without a CEO bonus for each variable is also shown. A $t$-test is used for continuous variables and a $\chi^{2}$-test for binary variables. All variables are defined in Appendix 1.

\begin{tabular}{|c|c|c|c|c|c|c|c|c|c|}
\hline & \multicolumn{3}{|c|}{ BONUS = 0 (138 observations) } & \multirow[b]{2}{*}{ Max } & \multicolumn{4}{|c|}{ BONUS = 1 (170 observations) } & \multirow{2}{*}{$\begin{array}{l}\text { Statistical } \\
\text { difference }\end{array}$} \\
\hline & Mean & Std. Dev. & Min & & Mean & Std. Dev. & Min & Max & \\
\hline$G W(\$ m)$ & 192 & 1,240 & 0.000 & 14000 & 228 & 688 & 0.000 & 5,100 & -0.327 \\
\hline$G W_{-} D V$ & 0.289 & 0.482 & 0.000 & 3.227 & 0.358 & 0.430 & 0.000 & 2.234 & -1.331 \\
\hline $\operatorname{IFRS}$ & 0.507 & 0.502 & 0.000 & 1.000 & 0.576 & 0.496 & 0.000 & 1.000 & 1.472 \\
\hline$B \_L E V$ & 1.399 & 4.096 & 0.009 & 41.691 & 2.022 & 3.798 & -3.109 & 22.455 & -1.382 \\
\hline BONUS $(\$ 000)$ & 0.000 & 0.000 & 0.000 & 0.000 & 552.245 & 881.773 & 0.000 & $8,072.93$ & $-7.355^{* * *} *$ \\
\hline$B I G 4$ & 0.645 & 0.480 & 0.000 & 1.000 & 0.900 & 0.301 & 0.000 & 1.000 & $29.434 * * *$ \\
\hline RELSIZE & 0.544 & 0.758 & 0.004 & 4.304 & 0.489 & 1.293 & 0.000 & 11.004 & 0.440 \\
\hline TOEHOLD & 0.147 & 0.198 & 0.000 & 0.877 & 0.150 & 0.188 & 0.000 & 0.880 & -0.128 \\
\hline FRIENDLY & 0.862 & 0.346 & 0.000 & 1.000 & 0.841 & 0.367 & 0.000 & 1.000 & 0.268 \\
\hline PREMIUM & 0.481 & 2.729 & -0.883 & 31.500 & 0.434 & 1.033 & -1.000 & 9.333 & 0.208 \\
\hline SAMEIND & 0.609 & 0.490 & 0.000 & 1.000 & 0.641 & 0.481 & 0.000 & 1.000 & 0.344 \\
\hline PAYCASH & 0.268 & 0.445 & 0.000 & 1.000 & 0.382 & 0.487 & 0.000 & 1.000 & $4.488 * *$ \\
\hline$T_{-} G W_{-} D V$ & 0.143 & 0.717 & 0.000 & 7.749 & 0.114 & 0.218 & 0.000 & 1.078 & 0.494 \\
\hline$T \_P P E \_D V$ & 0.429 & 1.425 & 0.000 & 13.658 & 0.440 & 1.598 & 0.000 & 15.876 & -0.060 \\
\hline$T \_I I A \_D V$ & 0.042 & 0.115 & 0.000 & 0.696 & 0.093 & 0.231 & 0.000 & 1.691 & $-2.354 * *$ \\
\hline$T_{-} M B$ & 2.686 & 4.563 & -0.171 & 36.776 & 2.542 & 3.599 & -0.171 & 25.955 & 0.311 \\
\hline$B \_M B$ & 3.190 & 5.866 & 0.210 & 42.690 & 3.025 & 3.867 & 0.180 & 38.790 & 0.296 \\
\hline$I I A(\$ m)$ & 48.8 & 368 & 0.000 & 4,300 & 106 & 350 & 0.000 & 2,500 & -1.383 \\
\hline$I I A \_D V$ & 0.142 & 0.337 & 0.000 & 1.862 & 0.150 & 0.277 & 0.000 & 1.313 & -0.234 \\
\hline
\end{tabular}




\section{Table 4 Correlation matrix}

This table presents a Pearson correlation matrix amongst the variables included in regression model (1). All variables are defined in Appendix 1.

\begin{tabular}{|c|c|c|c|c|c|c|c|c|c|c|c|c|c|c|c|c|c|c|c|c|c|}
\hline & & 1 & 2 & 3 & 4 & 5 & 6 & 7 & 8 & 9 & 10 & 11 & 12 & 13 & 14 & 15 & 16 & 17 & 18 & 19 & 20 \\
\hline 1 & $G W(\$ m)$ & 1.00 & & & & & & & & & & & & & & & & & & & \\
\hline 2 & $G W \_D V$ & 0.17 & 1.00 & & & & & & & & & & & & & & & & & & \\
\hline 3 & IFRS & 0.11 & 0.05 & 1.00 & & & & & & & & & & & & & & & & & \\
\hline 4 & $B \_L E V$ & 0.12 & 0.11 & 0.10 & 1.00 & & & & & & & & & & & & & & & & \\
\hline 5 & BONUS & 0.02 & 0.08 & 0.07 & 0.08 & 1.00 & & & & & & & & & & & & & & & \\
\hline 6 & BONUS $(\$ 000)$ & 0.13 & 0.06 & 0.06 & 0.33 & 0.39 & 1.00 & & & & & & & & & & & & & & \\
\hline 7 & BIG4 & 0.10 & 0.06 & 0.00 & 0.09 & 0.31 & 0.21 & 1.00 & & & & & & & & & & & & & \\
\hline 8 & RELSIZE & 0.06 & -0.04 & 0.06 & 0.01 & -0.03 & -0.09 & -0.16 & 1.00 & & & & & & & & & & & & \\
\hline 9 & TOEHOLD & -0.07 & -0.10 & -0.13 & -0.08 & 0.01 & -0.03 & 0.11 & -0.13 & 1.00 & & & & & & & & & & & \\
\hline 10 & FRIENDLY & -0.05 & 0.03 & 0.13 & 0.04 & -0.03 & -0.05 & -0.15 & 0.04 & -0.11 & 1.00 & & & & & & & & & & \\
\hline 11 & PREMIUM & -0.03 & 0.11 & 0.08 & -0.02 & -0.01 & -0.03 & 0.01 & -0.05 & -0.07 & 0.05 & 1.00 & & & & & & & & & \\
\hline 12 & INDSAME & -0.08 & -0.14 & -0.15 & -0.22 & 0.03 & -0.11 & -0.11 & 0.02 & 0.13 & -0.06 & -0.02 & 1.00 & & & & & & & & \\
\hline 13 & PAYCASH & -0.06 & 0.18 & -0.08 & -0.02 & 0.12 & 0.18 & 0.12 & -0.10 & 0.26 & -0.28 & -0.08 & -0.03 & 1.00 & & & & & & & \\
\hline 14 & $T \_G W \_D V$ & -0.02 & 0.42 & -0.05 & -0.02 & -0.03 & -0.02 & -0.06 & 0.06 & -0.08 & 0.04 & -0.04 & -0.06 & -0.01 & 1.00 & & & & & & \\
\hline 15 & $T \_P P E \_D V$ & -0.04 & 0.12 & 0.04 & 0.08 & 0.00 & 0.05 & -0.04 & -0.03 & 0.04 & 0.01 & -0.06 & 0.08 & 0.08 & 0.05 & 1.00 & & & & & \\
\hline 16 & $T \_I I A \_D V$ & -0.02 & 0.09 & -0.02 & -0.02 & 0.13 & 0.24 & 0.07 & -0.05 & -0.03 & -0.03 & 0.04 & -0.03 & 0.14 & 0.03 & -0.05 & 1.00 & & & & \\
\hline 17 & $T \_M B$ & 0.04 & 0.01 & 0.11 & -0.07 & -0.02 & -0.01 & -0.11 & 0.06 & -0.06 & -0.02 & 0.04 & -0.03 & -0.07 & -0.06 & -0.11 & -0.09 & 1.00 & & & \\
\hline 18 & $B \_M B$ & 0.03 & 0.08 & 0.17 & 0.31 & -0.02 & -0.01 & 0.08 & -0.06 & -0.09 & 0.05 & 0.40 & -0.09 & -0.07 & -0.04 & -0.05 & -0.02 & 0.09 & 1.00 & & \\
\hline 19 & $I I A(\$ m)$ & 0.01 & -0.05 & 0.00 & -0.05 & 0.01 & 0.05 & -0.01 & 0.00 & -0.14 & -0.01 & 0.05 & 0.03 & 0.12 & -0.05 & 0.35 & 0.01 & 0.03 & 0.07 & 1.00 & \\
\hline 20 & $I I A \_D V$ & 0.80 & 0.04 & 0.09 & 0.15 & 0.08 & 0.20 & 0.09 & 0.05 & -0.07 & 0.00 & -0.03 & -0.14 & -0.02 & -0.04 & 0.07 & 0.02 & 0.01 & -0.01 & 0.20 & 1.00 \\
\hline
\end{tabular}

Bold text denotes significance at $10 \%$ or lower 


\section{Table 5}

\section{What drives the allocation of the purchase price to goodwill?}

This table presents the results of estimating regression model (1) with the dependent variable measuring the proportion of the purchase price allocated to goodwill. Standard errors are clustered by year. Target firm industry fixed effects are included in each model but results are not reported. All variables are defined in Appendix 1. The following Tobit regression is used:

$G W \_D V=\alpha_{i}+\beta_{I} I F R S+\beta_{2} B \_L E V+\beta_{3} B O N U S+\beta_{4} I F R S x B O N U S+\beta_{5} B I G 4+\beta_{6} R E L S I Z E$

$+\beta_{7}$ TOEHOLD $+\beta_{8}$ FRIENDLY $+\beta_{9}$ PREMIUM $+\beta_{10} S A M E I N D+\beta_{11} P A Y C A S H+\beta_{12} T \_G W \_D V$

$+\beta_{13} T \_P P E \_D V+\beta_{14} T \_I I A \_D V+\beta_{15} T \_M B+\beta_{16} B \_M B+\varepsilon_{i}$

\begin{tabular}{lcrrr}
\hline & pred.sign & coeff & t-stat & p-value \\
\hline Intercept & $?$ & -0.616 & -2.51 & $0.01^{* * *}$ \\
Opportunism: & & & & \\
IFRS & + & 0.211 & 1.94 & $0.05^{* *}$ \\
B_LEV & - & 0.012 & 2.17 & $0.03^{* *}$ \\
BONUS & + & 0.248 & 2.78 & $0.01^{* * *}$ \\
BONUSXIFRS & + & -0.210 & -1.36 & 0.18 \\
BIG4 & + & 0.102 & 0.97 & 0.33 \\
RELSIZE & + & -0.033 & -1.16 & 0.25 \\
Takeovercharacteristics: & & & & \\
TOEHOLD & - & -0.223 & -1.10 & 0.27 \\
FRIENDLY & - & -0.013 & -0.12 & 0.902 \\
PREMIUM & + & 0.030 & 1.75 & $0.08 *$ \\
SAMEIND & + & -0.100 & -1.63 & $0.10^{*}$ \\
PAYCASH & $?$ & 0.166 & 2.34 & $0.02 * *$ \\
Economic characteristics: & & & & \\
T_GW_DV & + & 0.444 & 4.91 & $0.00^{* * *}$ \\
T_PPE_DV & - & 0.034 & 1.38 & 0.17 \\
T_IIA_DV & - & -0.143 & -0.79 & 0.43 \\
T_MB & + & 0.00 & 0.20 & 0.84 \\
B_MB & + & 0.00 & 0.34 & 0.73
\end{tabular}

Target industry fixed

effects yes

Observations 308

\begin{tabular}{ll} 
Pseudo R2 $24.01 \%$ \\
\hline
\end{tabular}

* $\quad$ Significant at the 1\% level; ** significant at the 5\% level; *** significant at the $10 \%$ level 


\section{Table 6}

\section{Bonus plan use and the allocation of the purchase price to goodwill}

This table presents the results of estimating regression model (1) separately for firms with and without an accounting based bonus plan. The dependent variable measures the proportion of the purchase price allocated to goodwill. Standard errors are clustered by year. Target firm industry fixed effects are included in each model but results are not reported. All variables are defined in Appendix 1. The following Tobit regression is used:

$G W_{-} D V=\alpha_{i}+\beta_{1} I F R S+\beta_{2} B_{-} L E V+\beta_{3} B I G 4+\beta_{4} R E L S I Z E+\beta_{5} T O E H O L D+\beta_{6} F R I E N D L Y+\beta_{7} P R E M I U M+\beta_{8} S A M E I N D+\beta_{9} P A Y C A S H+\beta_{10} T G G W_{-} D V$ $+\beta_{11} T \_P P E \_D V+\beta_{12} T \_I I A \_D V+\beta_{13} T \_M B+\beta_{14} B \_M B+\varepsilon_{i}$

\begin{tabular}{|c|c|c|c|c|c|c|c|}
\hline & \multirow[b]{2}{*}{ pred.sign } & \multicolumn{3}{|c|}{$\begin{array}{l}\text { CEO does not receive bonus compensation } \\
\text { BONUS }=0\end{array}$} & \multicolumn{3}{|c|}{$\begin{array}{c}\text { CEO receives bonus compensation } \\
\text { BONUS }=1\end{array}$} \\
\hline & & coeff & t-stat & p-value & coeff & t-stat & p-value \\
\hline Intercept & $?$ & -0.44 & -1.47 & 0.14 & -0.40 & -1.36 & 0.18 \\
\hline \multicolumn{8}{|l|}{ Opportunism: } \\
\hline$\overline{\text { IFRS }}$ & + & 0.30 & 2.22 & $0.03 * *$ & 0.00 & 0.00 & 0.99 \\
\hline$B \_L E V$ & - & 0.01 & -0.52 & 0.61 & 0.02 & 2.04 & $0.04 * *$ \\
\hline BIG4 & + & 0.14 & 0.90 & 0.37 & 0.11 & 0.84 & 0.40 \\
\hline RELSIZE & + & -0.11 & -0.85 & 0.40 & -0.01 & -0.34 & 0.74 \\
\hline \multicolumn{8}{|c|}{ Takeover characteristics: } \\
\hline TOEHOLD & - & 0.14 & 0.38 & 0.71 & -0.41 & -2.42 & $0.02 * *$ \\
\hline FRIENDLY & - & -0.31 & -1.78 & $0.08 *$ & 0.05 & 0.69 & 0.49 \\
\hline PREMIUM & + & 0.01 & 0.40 & 0.70 & 0.04 & 0.54 & 0.59 \\
\hline SAMEIND & + & -0.12 & -0.97 & 0.34 & -0.09 & -1.15 & 0.25 \\
\hline PAYCASH & $?$ & 0.11 & 0.98 & 0.33 & 0.16 & 1.69 & $010^{*}$ \\
\hline \multicolumn{8}{|c|}{ Economic characteristics } \\
\hline$T T_{-} G W \_D V$ & + & 0.50 & 5.10 & $0.00 * * *$ & 0.59 & 1.51 & 0.13 \\
\hline$T \_P P E \_D V$ & - & 0.04 & 0.87 & 0.39 & 0.02 & 0.60 & 0.55 \\
\hline$T \_I I A \_D V$ & - & 0.11 & 0.37 & 0.71 & -0.24 & -1.34 & 0.18 \\
\hline$T \_M B$ & + & 0.02 & 1.46 & 0.15 & -0.02 & -1.25 & 0.22 \\
\hline$B \_M B$ & + & 0.02 & 0.83 & 0.41 & 0.00 & 0.43 & 0.67 \\
\hline Target indust & & yes & & & yes & & \\
\hline Observations & & 138 & & & 170 & & \\
\hline Pseudo R2 & & $32.18 \%$ & & & $24.21 \%$ & & \\
\hline
\end{tabular}

* Significant at the 1\% level; ** significant at the 5\% level; *** significant at the $10 \%$ level 


\section{Appendix 1}

Variable names and definitions

\begin{tabular}{|c|c|}
\hline Variable name & Definition \\
\hline$G W$ & $\begin{array}{l}\text { The dollar value in thousands of the amount initially allocated to } \\
\text { goodwill }\end{array}$ \\
\hline$G W \_D V$ & The amount initially allocated to goodwill scaled by deal value \\
\hline IFRS & $\begin{array}{l}\text { An indicator variable denoting takeovers in which the first year of } \\
\text { consolidation of the takeover uses IFRS }\end{array}$ \\
\hline$B \_L E V$ & $\begin{array}{l}\text { Bidding firm ratio of debt to equity at the end of the financial year prior } \\
\text { to the takeover announcement }\end{array}$ \\
\hline BONUS & $\begin{array}{l}\text { An indicator variable denoting takeovers in which the bidding firm CEO } \\
\text { is compensated using a bonus plan based on accounting numbers }\end{array}$ \\
\hline BONUSXIFRS & An interaction variable between $B O N U S$ and $I F R S$ \\
\hline$B I G 4$ & $\begin{array}{l}\text { An indicator variable denoting takeovers in which the bidding firm } \\
\text { auditor is a Big Four firm for the first year of consolidation }\end{array}$ \\
\hline RELSIZE & $\begin{array}{l}\text { The natural logarithm of target firm to acquiring firm market } \\
\text { capitalisation two months before the takeover announcement }\end{array}$ \\
\hline TOEHOLD & $\begin{array}{l}\text { The toehold stake of the bidder in the target firm at the announcement of } \\
\text { the takeover }\end{array}$ \\
\hline FRIENDLY & $\begin{array}{l}\text { An indicator variable denoting target firms where the initial } \\
\text { recommendation of the target firm board is takeover acceptance }\end{array}$ \\
\hline PREMIUM & $\begin{array}{l}\text { The takeover premium calculated as the offer price minus the target } \\
\text { share price two months prior to the takeover announcement, divided by } \\
\text { the price two months prior to the takeover announcement }\end{array}$ \\
\hline SAMEIND & $\begin{array}{l}\text { An indicator variable denoting takeovers in which the target and bidder } \\
\text { firm have an identical two digit GICS code }\end{array}$ \\
\hline PAYCASH & $\begin{array}{l}\text { An indicator variable denoting takeovers in which the method of } \\
\text { payment is exclusively cash }\end{array}$ \\
\hline$T \_G W \_D V$ & $\begin{array}{l}\text { The amount of recorded target firm goodwill for the year prior to the } \\
\text { takeover scaled by deal value }\end{array}$ \\
\hline$T \_P P E \_D V$ & $\begin{array}{l}\text { The amount of recorded target firm property plant and equipment for the } \\
\text { year prior to the takeover scaled by deal value }\end{array}$ \\
\hline$T \_I I A \_D V$ & $\begin{array}{l}\text { The amount of recorded target firm identifiable intangible assets for the } \\
\text { year prior to the takeover scaled by deal value }\end{array}$ \\
\hline
\end{tabular}




\begin{tabular}{|l|l|}
\hline$T \_M B$ & $\begin{array}{l}\text { Target firm market-to-book ratio calculated two months prior to the } \\
\text { takeover announcement }\end{array}$ \\
\hline$B \_M B$ & $\begin{array}{l}\text { Bidding firm market-to-book ratio calculated two months prior to the } \\
\text { takeover announcement }\end{array}$ \\
\hline$I I A$ & $\begin{array}{l}\text { The dollar value in thousands of the amount initially allocated to } \\
\text { identifiable intangible assets }\end{array}$ \\
\hline$I I A \_D V$ & $\begin{array}{l}\text { The amount initially allocated to identifiable intangible assets scaled by } \\
\text { deal value }\end{array}$ \\
\hline
\end{tabular}

